\title{
Academic achievement, depression and anxiety during medical education predict the styles of success in a medical career: A 10-year longitudinal study
}

\author{
Maciej Walkiewicz, Malgorzata Tartas, Mikolaj Majkowicz \& Waldemar \\ Budzinski
}

To cite this article: Maciej Walkiewicz, Malgorzata Tartas, Mikolaj Majkowicz \& Waldemar Budzinski (2012) Academic achievement, depression and anxiety during medical education predict the styles of success in a medical career: A 10-year longitudinal study, Medical Teacher, 34:9, e611-e619

To link to this article: http://dx.doi.org/10.3109/0142159X.2012.687478

Published online: 21 Aug 2012.

Submit your article to this journal ¿

Ш Article views: 1324

View related articles 주 


\title{
Academic achievement, depression and anxiety during medical education predict the styles of success in a medical career: A 10-year longitudinal study
}

\author{
MACIEJ WALKIEWICZ, MALGORZATA TARTAS, MIKOLAJ MAJKOWICZ \& WALDEMAR BUDZINSKI \\ Medical University of Gdańsk, Poland
}

\begin{abstract}
Aim: Our study investigated the styles of success in the medical career in young physicians, in comparison with the same subjects examined 4-10 years earlier.

Methods: The participants were first studied when they applied to the medical university (1999). Questionnaires were sent to all students each year (2000-2005). Fifty-four medical doctors participated in the first phase of the study completed a questionnaire four years after graduation. The current questionnaire included measures of burnout, satisfaction with medicine as a career, quality of life (QOL) and postgraduate examination results. Previous questionnaires had included measures of academic achievement, depression and anxiety.

Results: We can describe three different styles of success, which can be predicted during medical education. Physicians with the best professional competence have the lowest income. However, physicians with the lowest professional competence gain the highest income. Those with the highest QOL (general well-being and life satisfaction) have the lowest professional stress and vulnerability to burnout. Anxiety and academic achievement (during the second and fourth year of study) are the significant predictors of specific style belonging.
\end{abstract}

Conclusions: Our results may be useful to medical school admissions and resident selection committees to identify candidates at risk for less satisfaction or less competence.

\section{Introduction}

A review of the literature shows that it is not easy to define success in a medical career. Success in undergraduate medical training is usually defined as academic achievement, but this is an imperfect predictor of professional competency (Ferguson et al. 2002; Peskun et al. 2007). Success in the medical career is often measured in terms of postgraduate education results (postgraduate medical competence), satisfaction with medicine as a career, stress, burnout, research output, career progression and dropouts (Ferguson et al. 2002; McManus et al. 2003; Goho \& Blackman 2006). On the other hand, there are neither serious methodological problems involved with studying markers of success in clinical practice (large numbers of correct diagnoses, accurate prescriptions, efficient treatments and different aspects of doctor-patient relations), nor is it easy to establish a comparable scoring system for assessing these parameters in different medical specialties (Rippey et al. 1981; McManus et al. 1998).

Medical professionals are exposed to high workloads, and they suffer considerable levels of stress, which, in some cases, result in deterioration of mental health (Guthrie et al. 1998; Pickard et al. 2000; Inam et al. 2003; Radcliffe \& Lester 2003; Kiessling et al. 2004; Dahlin et al. 2005; Dyrbye et al. 2006,

\section{Practice points}

- We established a model of success in the medical career that includes: anxiety and academic achievement during medical school as predictors of success and markers of this success: postgraduate medical competence, satisfaction with medicine as a career, work stress and burnout and QOL.

- We described three different styles of success, which can be predicted during medical education based on factors of our model

2008; Niemi \& Vainiomaki 2006; Compton et al. 2008; Roh et al. 2009). Some studies have shown that depression and anxiety are negative predictors of success in the medical career (Miller \& Surtees 1991; Pamphlett \& Farnill 1995; Stewart et al. 1999). Medical students who began school with a relatively high level of anxiety and depression were found to be at higher risk for developing depression and anxiety symptoms later during medical studies (Stewart et al. 1997); they are not psychologically well in middle age and are vulnerable to burnout in the future (McCranie \& Brandsma 1988; NewburyBirch \& Kamali 2001; McManus et al. 2004). 
The early identification of individuals belonging to the risk group is important, not only for those in charge of providing well-being programs and mental health services for medical students, but also for those in charge of admissions to medical schools (Hughes 2002; Ferguson et al. 2003; Brennan et al. 2010; Paro et al. 2010). We could be fairer to applicants, and begin the process of education by showing that we are very serious about the kind of personal qualities that we want a physician to possess. We could increase the supply of wellmotivated and satisfied physicians (Hughes 2002).

There are also many research results indicating a need for transparent and effective admission systems, as well as tools for assessing the non-cognitive abilities that may be significant in the medical career (McManus et al. 2005; Cave et al. 2007; Bore et al. 2009; Fernando et al. 2009; Powis 2009; O'Neill et al. 2009; White et al. 2009).

Research has provided evidence that there is no global model describing success in the medical career, including quality of life (QOL). Current information about the QOL of Polish physicians can be found in a report entitled 'Social Diagnosis: Objective and Subjective Quality of Life in Poland' (Czapinski \& Panek 2000, 2003, 2005, 2007, 2009, 2011). The 'Social Diagnosis' project is the world's largest longitudinal psychological study of QOL in the population of a specific country ( $n=26,178$; Polish population $n=38,204,000$ ). The results of this study characterise well-being and life satisfaction in Polish medical doctors in comparison with other occupational groups. This study was our inspiration to develop a model of success in the medical career. Thus, background of this specific model was based on well-being and life satisfaction, as well as on some complementary factors mentioned by Gattiker and Larwood in their model of career success, such as job success (performance and happiness at work) and financial success (Gattiker \& Larwood 1986).

In our previous research, we determined which psychological factors predict success in the medical career (Tartas et al. 2011). The methodology and the sample were exactly the same as in this research. Success in medicine was defined as professional competence, satisfaction with medicine as a career, work stress and vulnerability to burnout and finally the QOL. We found that academic achievement explains only professional competence. What is puzzling is the fact that the grades obtained during the whole of medical studies are related to an insignificant extent to the professional examination, whose result determines the possibility of beginning a medical specialisation in Poland. However, satisfaction with medicine as a career and the level of work stress and burnout related to performing this job are additionally conditioned by anxiety and depression among other psychological characteristics. What is more, in that study we analysed the QOL of these physicians by taking into account three aspects: general well-being and health, life satisfaction and income. The QOL was found to depend on earlier psychological characteristics and not on academic achievement. With reference to our model, what can be predicted most accurately is general wellbeing and health, whereas life satisfaction can be predicted to a lower extent, and the amount of future income can hardly be determined. QOL is shaped by the depression and anxiety levels. It is worth noting that, on the basis of these results, each e612 subsequent year of medical studies can provide more information about the factors conditioning success in a medical career. The first 3 years of studies provide only a source of knowledge about the indicators of future success in professional life: satisfaction with medicine as a career and the level of stress. Meanwhile, from the third year of studies onwards (the clinical years), predictions can be made about the future QOL of doctors: their general well-being and health, their life satisfaction and the amount of income. One asset of the presented model of factors related to the success in a medical career would seem to be the fact that most of the differentiated indicators are also dependent on clinical symptoms of inadequate personality mechanisms, such as anxiety and depression. Therefore, success in a medical career seems to be the consequence of the level of personality structure integration, and not a simple result of the medical education process.

Finally, we established a model based on the model of success existing in the literature (Gattiker \& Larwood 1986), Polish longitudinal psychological study of QOL (Czapinski \& Panek 2000, 2003, 2005, 2007, 2009, 2011) and our previous findings on predictors of success (academic achievements, depression and anxiety) and markers of this success (postgraduate medical competence, satisfaction with medicine as a career, work stress and burnout and QOL; Tartas et al. 2011). In the context of the obtained data, our goal was to find out potential areas useful to estimate professional development in the medical career. Thus, our longitudinal study was designed to explore styles of success in the medical career within 4 years of graduation, and to determine differences between the results at admission and during medical school in terms of academic achievement, depression and anxiety (Figure 1).

\section{Methods}

\section{Institution}

The Medical University of Gdańsk is the largest medical school in northern Poland and educates (in Polish and English) more than 5000 undergraduate and postgraduate students in four faculties: Health Sciences, Medicine, Pharmacy and Biotechnology. The admission requirements are based on the high school final examination results and the medical school admission test until year 2005. Medical school admission test included three basic subjects: biology, chemistry and physics. It was used locally only and prepared by the Medical University of Gdańsk. The university accepted the candidates who achieved the best test results. In 1999, it was the best 320 people for the first year of study. Medical training in Poland lasts for six years, and is divided into two years of basic science and four years of clinical training. Graduates must complete one year of internship, providing medical assistance under supervision, mainly in hospital settings. They gain a license to practice medicine when they pass the State Examination for Medical Doctors. The test results determine whether or not further medical specialisation will be possible. This longitudinal research program was conducted in compliance with the guidelines of the Bioethics Committee of the Medical University of Gdańsk, Poland, which reviewed and approved the project. 


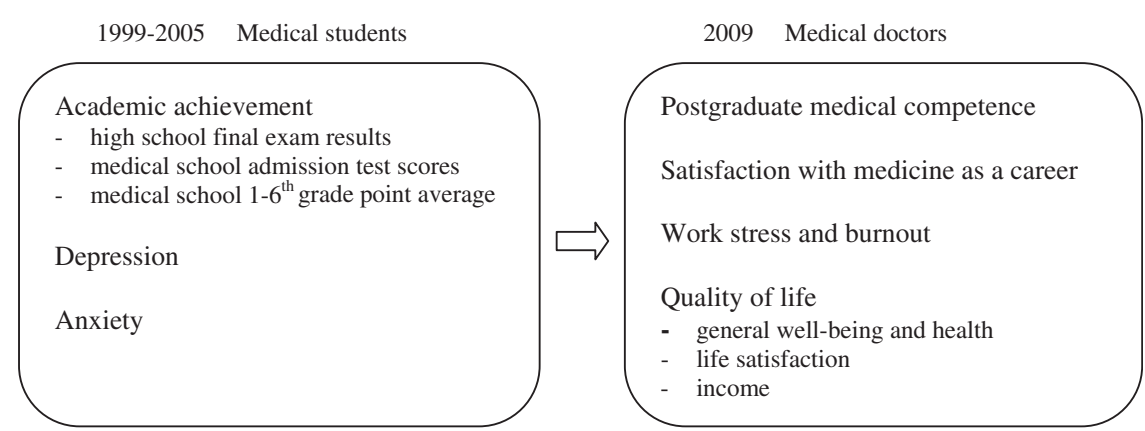

Figure 1. Model of success predictors (academic achievement, depression and anxiety during medical education) and markers of success four years after graduation.

\section{Participants}

The first part of this study took place a few days before the admission test in June 1999. All individuals $(n=940)$ who had applied to the Medical University of Gdańsk received a letter with questionnaires (the response rate was 39\%, $n=365$ ). Only those who passed the admission exam were taken into consideration for the purposes of our research $(n=320)$. The procedure was repeated subsequently at the end of every academic year (2000-2005). Questionnaires were sent to all medical students. They were told that we were evaluating personality characteristics during medical school.

Over a period of four years after graduation, the authors cooperated with institutions responsible for postgraduate medical education in Poland. The Medical Examination Centre in Poland provided access to the examination results of postgraduates (the State Examination for Medical Doctors) for 268 identified physicians ( $n=268$ of $320,84 \%$ response rate). We also cooperated with the Polish Chamber of Physicians and Dentists in Gdańsk, Poland, where we found the addresses of 255 medical doctors who had participated in the first part of the study. The response rate in this group was $21 \%(n=54)$. The mean age of respondents as of 1 July 2009 was $29.5 \pm 0.8$ years (69\% female). The response rate was as follows:

\section{Measures}

\begin{tabular}{|c|c|c|c|c|}
\hline \multicolumn{5}{|c|}{ Final sample $(n=54)$ response rate } \\
\hline & $\begin{array}{l}\text { General } \\
\text { response } \\
\text { rate }\end{array}$ & $\begin{array}{c}\text { Academic } \\
\text { achievement* }\end{array}$ & Depression & Anxiety \\
\hline Admission, & $n=178$ of $320(56 \%)$ & $n=45(83 \%)$ & $n=31(57 \%)$ & $n=29(54 \%) ;$ \\
\hline In year 1 & $n=178$ of $320(56 \%) ;$ & $n=42(77 \%)$ & $n=32$ (59\%); & $n=32(59 \%)$ \\
\hline In year 2 & $n=129$ of $280(46 \%)$ & $n=41(76 \%)$ & $n=21$ (39\%); & $n=22(41 \%) ;$ \\
\hline In year 3 & $n=127$ of $302(42 \%)$ & $n=41(76 \%)$ & $n=23(43 \%)$ & $n=20(37 \%) ;$ \\
\hline In year 4 , & $n=121$ of $288(42 \%)$ & $n=41(76 \%)$ & $n=21$ (39\%); & $n=20(37 \%) ;$ \\
\hline In year 5 & $n=58$ of $271(21 \%)$ & $n=10(19 \%)$ & $n=10(19 \%)$ & $n=9(17 \%)$ \\
\hline In year 6 , & $n=138$ of $240(57 \%)$ & $n=18$ (33\%); & $n=18$ (33\%); & $n=19(35 \%)$ \\
\hline
\end{tabular}

Academic achievement was measured by high school final exam results, medical school admission test scores and grades received during medical school (1-6th grade point average (GPA) scores).

Depression was measured by the Depression Scale from Hathaway and McKinley's Minnesota Multiphasic Personality Inventory (MMPI-D). The Depression Scale measures discomfort and dissatisfaction with life, characterised by poor morale, lack of hope for the future, denial of happiness and self-worth, withdrawal, psychomotor retardation and other symptoms of symptomatic depression (Matkowski 1992; Hathaway \& McKinley 1943, 1951).

Symptoms of anxiety were evaluated by Spielberger's State-Trait Anxiety Inventory. State anxiety indicates a temporary level of anxiety related to the present moment, whereas trait anxiety indicates a stable personality dimension (Spielberger et al. 1970; Spielberger 1966; Wrześniewski \& Sosnowski 1996).

The assessment of success in the medical career included postgraduate medical competence, work stress and burnout, satisfaction with medicine as a career and QOL.

The first aspect of success in medical career - medical competence was measured by examination results on the State Examination for Medical Doctors, supplied by the Medical Examination Centre in Poland. The exam is executed during the postgraduate internship, and it is required to gain a license to practice medicine. The results determine whether or not further medical specialisation will be possible. The exam is organised by the Medical Examination Centre every spring and autumn. The exam starts at the same moment in 11 districts in Poland. The exam is multiple choice test. Subject matter includes: internal medicine, paediatrics, surgery, gynaecology and obstetrics, psychiatry, family medicine, emergency medicine and intensive care, oncology, bioethics and medical law, public health and medical jurisdiction.

The second aspect of success in medical career - burnout, was measured by the Maslach burnout inventory, which has three sub-scales: emotional exhaustion, depersonalisation and personal accomplishment (Maslach \& Jackson 1986; Pasikowski 2000).

The third aspect of success in medical career - satisfaction with medicine as a career was measured by a self-designed survey (Cronbach's alpha $=0.80 ; r=0.67$ ).

The fourth aspect of success in medical career - QOL was measured by a questionnaire derived from 'Social Diagnosis: Objective and Subjective Quality of Life in Poland' (Czapinski \& Panek 2000, 2003, 2005, 2007, 2009, 2011). QOL consisted of:

(1) General well-being and health (Cronbach's alpha $=0.74, r=0.40)$. 
Table 1. Descriptions of the three styles of success in a medical career dimensions: cluster analysis (bineary Euclidean distance measure and Ward's linkage method).

\begin{tabular}{|c|c|c|c|c|c|c|c|c|}
\hline & \multirow{2}{*}{$\begin{array}{l}\text { 1. Committed } \\
\text { satisfied } \\
\text { with career } \\
n=14 \\
M \pm S D\end{array}$} & \multirow{2}{*}{$\begin{array}{l}\text { 2. Clever } \\
\text { satisfied } \\
\text { with life } \\
n=20 \\
M \pm S D\end{array}$} & \multirow{2}{*}{$\begin{array}{c}\text { 3. Bright } \\
\text { competent } \\
\begin{array}{c}n=16 \\
\mathrm{M} \pm \mathrm{SD}\end{array}\end{array}$} & \multirow{2}{*}{$F(2 ; 47)$} & \multirow{2}{*}{$p$} & \multicolumn{3}{|c|}{ Tukey's post- hoc test } \\
\hline & & & & & & 1 vs. 2 & 1 vs. 3 & 2 vs. 3 \\
\hline Postgraduate medical competence & $-0.62 \pm 0.61$ & $-0.50 \pm 0.53$ & $1.17 \pm 0.61$ & $48.256^{\star \star \star}$ & $<0.001$ & 0.53 & $<0.001^{\star \star \star}$ & $0.00^{* *}$ \\
\hline Satisfaction with medicine as a career & $0.95 \pm 0.68$ & $-0.47 \pm 0.47$ & $-0.24 \pm 0.85$ & $20.180^{\star \star \star}$ & $<0.001$ & $<0.001^{\star \star \star}$ & $<0.001^{\star \star \star}$ & 0.31 \\
\hline Work stress and burnout & $0.33 \pm 0.48$ & $-0.27 \pm 0.43$ & $0.07 \pm 0.45$ & $7.365^{\star \star \star}$ & $<0.001$ & $<0.001^{\star \star \star}$ & 0.13 & $0.03^{\star}$ \\
\hline QOL General well-being & $-0.29 \pm 0.81$ & $0.49 \pm 0.55$ & $-0.35 \pm 0.60$ & $9.499^{\star \star \star}$ & $<0.001$ & $<0.001^{\star \star \star}$ & 0.80 & $<0.001^{\star \star \star}$ \\
\hline QOL Life satisfaction & $-0.60 \pm 0.78$ & $0.76 \pm 0.45$ & $-0.89 \pm 0.86$ & $29.090^{\star \star \star}$ & $<0.001$ & $<0.001^{\star \star \star}$ & 0.26 & $<0.001^{\star \star \star}$ \\
\hline QOL Income & $3.57 \pm 0.51$ & $3.80 \pm 0.41$ & $2.63 \pm 0.89$ & $16.803^{\star \star \star}$ & $<0.001$ & 0.31 & $<0.001^{\star \star *}$ & $<0.001^{\star \star *}$ \\
\hline
\end{tabular}

${ }^{*} p<0.05 ;{ }^{* *} p<0.01 ;{ }^{* \star *} p<0.001$.

(2) Life satisfaction - 22 questions about different aspects of human life: social, financial, surroundings and health (Cronbach's alpha $=0.83 ; r=0.25$ ).

(3) Size of income.

\section{Statistical analysis}

All the statistical methods were used because of the methodology of exploratory research where the use of the subsequent analyses is dependent on the previous outcomes.

In the first stage, cluster analysis (using the Binary Euclidean distance measure and Ward's linkage method) was used to identify styles of success in the medical career. The aim of cluster analysis is to find, using mathematical algorithms, groups (styles, clusters and types) of homogeneous items or persons who are similar to each other and who differ from other groups.

In the second stage, ANOVA analysis of variance was used to determine differences between clusters during medical studies, cross-checking with academic achievement and depression and anxiety.

The number of groups differentiated on the basis of the cluster analysis was not explicit. Three clusters differentiated initially were the result of a comparative analysis of several models. $F$ statistic and effect size were the background for the choice three group model as explanation of the largest part of the variances. It appeared that, e.g. trait anxiety variable differentiated specific styles of success even during medical study. It seems to be relatively stable characteristic. Hence, it could imply that the results of ANOVA show differences due to the wise family data error.

For the reduction of wise family data error in the third step, discriminant analysis (with backward method using Ward's estimate) was involved. The predictors were variables from ANOVA and dependent variables were clusters (styles of success).

The survey research was conducted according to the longitudinal paradigm for 10 years. The results of such studies often lack a significant number of random missing data. To remove data gaps, they were replaced by linear interpolation using existing past data as predictors in the same or similar variables. For example, missing data on anxiety on the sixth year of study were replaced by a linear combination of existing e614 data in anxiety measures at first, second, third, fourth and fifth years.

\section{Results}

We were able to identify three styles of success. We have termed the first style 'Committed - satisfied with career', the second style 'Clever - satisfied with life' and the third style 'Bright - competent'. There are significant differences between them in terms of postgraduate medical competence, satisfaction with medicine as a career, work stress and burnout and all three QOL parameters: general well-being and health, life satisfaction and income (Table 1).

We may assume that physicians who belong to the first cluster ('Committed - satisfied with career') are the most committed to their work. The 'Committed' have the lowest competence. They have significantly lower level of professional competence than the 'Bright'. They declare the highest level of satisfaction with medicine as a career (significantly higher than the 'Clever' and the 'Bright'). At the same time, they have the highest level of work stress and burnout (higher than the 'Clever'). They are not very happy or satisfied with life, even though their income is high. The 'Committed' have significantly higher level of general well-being and life satisfaction than the 'Clever', and they have a considerably higher income than the 'Bright'.

We can reasonably suppose that physicians who fit the second style (the 'Clever - satisfied with life') are the least committed to their work, but they derive the most benefit from it. Physicians who fit the second style have low medical competence (significantly lower than the 'Bright'). They declare the lowest level of satisfaction with medicine as a career and the lowest level of work stress and burnout. They have considerably lower level of satisfaction with medicine than the 'Committed' and significantly lower level of work stress and burnout than the 'Committed' and the 'Bright'. On the other hand, their QOL is the highest. They are the happiest, the most satisfied with their life and they obtain the highest income. The 'Clever' have significantly higher level of general well-being and life satisfaction than the 'Committed' and the "Bright'. They also have considerably higher income than the 'Bright'. 
Table 2. Means ( \pm standard deviation) for groups representing the styles of success in the medical career, in terms of academic achievement, depression and anxiety at admission and during medical school.

\begin{tabular}{|c|c|c|c|c|c|c|c|c|c|}
\hline & \multirow{2}{*}{$\begin{array}{l}\text { 1. Committed } \\
\text { satisfied with } \\
\text { career } n=14 \\
\qquad M \pm S D\end{array}$} & \multirow{2}{*}{$\begin{array}{l}\text { 2. Clever } \\
\text { satisfied with } \\
\text { life } n=20 \\
\quad M \pm S D\end{array}$} & \multirow{2}{*}{$\begin{array}{c}\text { 3. Bright } \\
\text { competent } \\
\begin{array}{c}n=16 \\
\mathrm{M} \pm \mathrm{SD}\end{array}\end{array}$} & \multirow[b]{2}{*}{$F(2 ; 47)$} & \multirow[b]{2}{*}{$p$} & \multirow[b]{2}{*}{$\eta^{2}$} & \multicolumn{3}{|c|}{ Tukey's post- hoc test } \\
\hline & & & & & & & 1 vs. 2 & 1 vs. 3 & 2 vs. 3 \\
\hline \multicolumn{10}{|c|}{ High school final exam results } \\
\hline Biology & $5.29 \pm 0.47$ & $4.80 \pm 0.41$ & $4.88 \pm 0.81$ & 3.141 & 0.052 & 0.13 & & & \\
\hline Chemistry & $5.00 \pm 0.78$ & $4.50 \pm 0.69$ & $4.75 \pm 0.45$ & 2.444 & 0.098 & 0.10 & & & \\
\hline Physics & $4.71 \pm 0.47$ & $4.50 \pm 0.83$ & $4.38 \pm 0.72$ & 0.869 & 0.426 & 0.04 & & & \\
\hline Total & $15.00 \pm 1.11$ & $13.80 \pm 1.70$ & $14.00 \pm 1.46$ & 2.915 & 0.064 & 0.12 & & & \\
\hline \multicolumn{10}{|c|}{ Medical school admission test scores } \\
\hline Biology & $26.43 \pm 2.82$ & $26.10 \pm 3.63$ & $28.25 \pm 3.61$ & 1.931 & 0.156 & 0.08 & & & \\
\hline Chemistry & $29.71 \pm 3.07$ & $29.70 \pm 3.20$ & $29.75 \pm 4.31$ & 0.001 & 0.999 & 0.00 & & & \\
\hline Physics & $26.86 \pm 3.82$ & $26.70 \pm 4.84$ & $28.13 \pm 4.40$ & 0.517 & 0.599 & 0.02 & & & \\
\hline Total & $82.86 \pm 7.28$ & $82.30 \pm 7.37$ & $85.88 \pm 9.57$ & 0.944 & 0.396 & 0.04 & & & \\
\hline \multicolumn{10}{|c|}{ Medical school 1-6th grade point average } \\
\hline Year 1 & $3.61 \pm 0.37$ & $3.42 \pm 0.26$ & $3.63 \pm 0.43$ & 2.028 & 0.143 & 0.09 & & & \\
\hline Year 2 & $3.68 \pm 0.38$ & $3.42 \pm 0.29$ & $3.81 \pm 0.39$ & $5.723^{\star \star}$ & 0.006 & 0.24 & 0.09 & 0.09 & $0.01^{*}$ \\
\hline Year 3 & $3.67 \pm 0.40$ & $3.51 \pm 0.20$ & $3.76 \pm 0.51$ & 2.058 & 0.139 & 0.09 & & & \\
\hline Year 4 & $3.89 \pm 0.60$ & $3.58 \pm 0.20$ & $3.97 \pm 0.62$ & 3.147 & 0.052 & 0.13 & & & \\
\hline Year 5 & $4.03 \pm 0.24$ & $3.85 \pm 0.24$ & $3.98 \pm 0.21$ & 2.802 & 0.071 & 0.12 & & & \\
\hline Year 6 & $3.99 \pm 0.28$ & $3.91 \pm 0.28$ & $4.05 \pm 0.10$ & 1.458 & 0.243 & 0.06 & & & \\
\hline \multicolumn{10}{|c|}{ Depression } \\
\hline Year 0 & $42.14 \pm 12.41$ & $33.50 \pm 8.73$ & $48.25 \pm 9.98$ & $10.666^{\star \star \star}$ & $<0.001$ & 0.45 & $0.03^{\star}$ & 0.20 & $0.00^{\star \star}$ \\
\hline Year 1 & $43.57 \pm 11.79$ & $35.30 \pm 8.11$ & $53.13 \pm 10.27$ & $14.318^{\star \star \star}$ & $<0.001$ & 0.61 & 0.05 & $0.03^{\star}$ & $0.00^{\star \star}$ \\
\hline Year 2 & $41.00 \pm 11.02$ & $35.40 \pm 9.64$ & $46.63 \pm 12.40$ & $4.672^{\star}$ & 0.014 & 0.20 & 0.32 & 0.35 & $0.01^{\star}$ \\
\hline Year 3 & $45.43 \pm 11.19$ & $36.60 \pm 11.44$ & $47.00 \pm 10.83$ & $3.500^{*}$ & 0.038 & 0.15 & 0.13 & 0.94 & 0.05 \\
\hline Year 4 & $50.00 \pm 11.65$ & $39.50 \pm 12.11$ & $47.13 \pm 11.34$ & $3.723^{*}$ & 0.032 & 0.16 & $0.01^{\star}$ & $0.01^{\star}$ & 0.86 \\
\hline Year 5 & $52.43 \pm 13.66$ & $34.30 \pm 9.68$ & $42.13 \pm 12.10$ & $11.177^{\star \star \star}$ & $<0.001$ & 0.48 & $0.00^{\star \star}$ & $0.04^{\star}$ & 0.10 \\
\hline Year 6 & $47.57 \pm 13.21$ & $35.50 \pm 10.11$ & $40.75 \pm 11.60$ & $4.997^{\star}$ & 0.011 & 0.21 & $0.01^{\star}$ & 0.22 & 0.34 \\
\hline \multicolumn{10}{|c|}{ State anxiety } \\
\hline Year 0 & $17.86 \pm 32.79$ & $2.20 \pm 1.01$ & $5.00 \pm 2.78$ & $3.603^{*}$ & 0.035 & 0.15 & $0.03^{\star}$ & 0.12 & 0.88 \\
\hline Year 1 & $4.83 \pm 1.29$ & $4.20 \pm 1.77$ & $6.75 \pm 1.98$ & $3.423^{*}$ & 0.041 & 0.15 & $0.04^{*}$ & 0.13 & 0.90 \\
\hline Year 2 & $4.71 \pm 1.64$ & $3.60 \pm 1.31$ & $5.88 \pm 2.70$ & $6.108^{\star \star}$ & 0.004 & 0.26 & 0.24 & 0.24 & $0.00^{\star *}$ \\
\hline Year 3 & $5.86 \pm 2.44$ & $4.20 \pm 2.33$ & $6.13 \pm 2.55$ & $3.324^{\star}$ & 0.045 & 0.14 & 0.14 & 0.95 & 0.06 \\
\hline Year 4 & $5.57 \pm 2.28$ & $4.10 \pm 1.97$ & $5.75 \pm 2.46$ & 3.005 & 0.059 & 0.13 & & & \\
\hline Year 5 & $5.57 \pm 2.14$ & $3.50 \pm 2.12$ & $5.75 \pm 2.46$ & $5.647^{\star \star}$ & 0.006 & 0.24 & $0.03^{\star}$ & 0.97 & $0.01^{*}$ \\
\hline Year 6 & $4.71 \pm 1.90$ & $3.50 \pm 2.12$ & $5.75 \pm 2.46$ & $4.794^{*}$ & 0.013 & 0.20 & 0.26 & 0.40 & $0.01^{*}$ \\
\hline \multicolumn{10}{|c|}{ Trait anxiety } \\
\hline Year 0 & $5.57 \pm 1.31$ & $3.10 \pm 1.41$ & $5.88 \pm 2.33$ & 3.041 & 0.057 & 0.13 & & & \\
\hline Year 1 & $18.57 \pm 33.24$ & $3.80 \pm 1.36$ & $7.63 \pm 1.54$ & 3.016 & 0.059 & 0.13 & & & \\
\hline Year 2 & $5.43 \pm 2.41$ & $3.80 \pm 1.36$ & $6.75 \pm 1.61$ & $12.309^{\star \star \star}$ & $<0.001$ & 0.52 & $0.03^{*}$ & 0.12 & $0.00^{\star \star}$ \\
\hline Year 3 & $5.86 \pm 2.32$ & $4.30 \pm 2.43$ & $6.50 \pm 1.71$ & $4.827^{\star}$ & 0.012 & 0.21 & 0.11 & 0.70 & $0.01^{*}$ \\
\hline Year 4 & $5.86 \pm 2.51$ & $4.00 \pm 2.25$ & $6.63 \pm 1.78$ & $6.885^{\star \star}$ & 0.002 & 0.29 & 0.05 & 0.61 & $0.00^{\star \star}$ \\
\hline Year 5 & $6.29 \pm 2.20$ & $3.80 \pm 1.51$ & $6.88 \pm 1.67$ & $15.370^{\star \star \star}$ & $<0.001$ & 0.65 & $0.00^{\star \star}$ & 0.64 & $0.00^{\star \star}$ \\
\hline Year 6 & $5.57 \pm 2.47$ & $3.80 \pm 1.51$ & $6.75 \pm 1.61$ & $11.558^{\star \star \star}$ & $<0.001$ & 0.49 & $0.02^{*}$ & 0.20 & $0.00^{\star \star}$ \\
\hline
\end{tabular}

${ }^{*} p<0.05 ;{ }^{* *} p<0.01 ;{ }^{* * *} p<0.001$.

Physicians belonging to the third cluster (the 'Bright competent') are the most competent, but they have problems with managing their lives. This is the group of doctors who are the most competent, but they are dissatisfied with medicine as a career. The 'Bright' have higher level of competence than the 'Committed' and the 'Clever'. They have a lower level of satisfaction with medicine than the 'Committed'. What is more, they declare a moderate level of work stress and burnout (significantly higher than the 'Clever'). Their QOL is the lowest. They are the saddest, the most dissatisfied with their life and their income is the lowest. The 'Bright' have lower level of general well-being and life satisfaction than the 'Clever' and lower level of income than the 'Committed' and the 'Bright'.

There are no significant differences between the styles in terms of high school final exam results (Table 2). There are also no significant differences in terms of medical school admission test scores. We did find a significant difference in medical school 1-6th GPA between physicians belonging to the different styles of success, but only in the second year of medical school. The 'Committed - satisfied with career' have a medium GPA in the second year, the 'Clever - satisfied with life' have the lowest GPA and the 'Bright - competent' have the highest GPA. The 'Bright' have significantly lower GPA than the 'Clever'. We also observed some trends that were close to being statistically significant: the 'Committed - satisfied with career' have higher high school final exam results, whereas the 'Bright - competent' have better medical school admission test results and higher GPA.

There are significant differences in terms of depression and anxiety among physicians who fit the different styles of success. 
Table 3. Discriminant analysis for groups representing the styles of success in the medical career, in terms of academic achievement depression and anxiety at admission and during medical school education.

\begin{tabular}{|c|c|c|c|c|c|c|}
\hline & \multicolumn{3}{|c|}{ Classification function } & \multicolumn{3}{|c|}{ Effect sources } \\
\hline & $\begin{array}{l}\text { 1. Committed } \\
\text { satisfied with } \\
\text { career } N=14 \\
p=0.28\end{array}$ & $\begin{array}{l}\text { 2. Clever } \\
\text { satisfied with } \\
\text { life } n=20 \\
p=0.40\end{array}$ & $\begin{array}{c}\text { 3. Bright } \\
\text { competent } \\
n=16 \\
p=0.32\end{array}$ & Wilks' $\lambda$ & $F(2 ; 44)$ & $p$ \\
\hline \multicolumn{7}{|c|}{ High school final exam results } \\
\hline Biology & 6.00 & 5.16 & 3.58 & 0.831 & $4.482^{\star}$ & 0.017 \\
\hline \multicolumn{7}{|c|}{ Medical school 1-6th grade point average } \\
\hline Year 2 & 27.36 & 23.43 & 31.66 & 0.742 & $7.654^{\star \star}$ & 0.001 \\
\hline Year 3 & -8.01 & -4.43 & -9.54 & 0.887 & 2.814 & 0.071 \\
\hline Year 4 & 13.24 & 11.44 & 14.26 & 0.848 & $3.943^{*}$ & 0.027 \\
\hline \multicolumn{7}{|c|}{ State anxiety } \\
\hline Year 0 & 466.92 & 387.40 & 332.80 & 0.11 & $110.560^{\star \star \star}$ & $<0.001$ \\
\hline Year 1 & -6.44 & -6.56 & -7.11 & 0.636 & $8.001^{\star \star}$ & 0.002 \\
\hline Year 2 & $-90,216.00$ & $-97,930.00$ & $-95,908.00$ & 0.003 & $4577.420^{\star \star \star}$ & $<0.001$ \\
\hline Year 3 & $531,692.00$ & $615,975.00$ & $619,943.00$ & $<0.001$ & $41,899.700^{\star \star \star}$ & $<0.001$ \\
\hline Year 5 & -7802.00 & $-11,151.00$ & $-10,620.00$ & 0.025 & $506.393^{\star \star \star}$ & $<0.001$ \\
\hline Year 6 & $-36,3711.00$ & $-464,364.00$ & $-452,881.00$ & 0.003 & $8242.350^{\star \star \star}$ & $<0.001$ \\
\hline \multicolumn{7}{|c|}{ Trait anxiety } \\
\hline Year 0 & -397.07 & -330.52 & -284.65 & 0.13 & $88.983^{\star \star \star}$ & $<0.001$ \\
\hline Year 2 & $90,510.00$ & $98,251.00$ & $96,222.00$ & 0.003 & $4223.860^{\star \star \star}$ & $<0.001$ \\
\hline Year 3 & $-928,693.00$ & -1075941.00 & -1082866.00 & $<0.001$ & $29,217.800^{\star \star \star}$ & $<0.001$ \\
\hline Year 5 & -778.00 & -1176.00 & -1134.00 & 0.487 & $13.689^{\star \star \star}$ & $<0.001$ \\
\hline Year 6 & $-26,739.00$ & $-34,143.00$ & $-33,299.00$ & 0.066 & $366.340^{\star \star \star}$ & $<0.001$ \\
\hline
\end{tabular}

${ }^{\star} p<0.05 ;{ }^{* *} p<0.01 ;{ }^{* \star *} p<0.001$.

The levels of depression (Table 2) in the different groups vary throughout medical school. The 'Committed' have a moderate level of depression from admission to the third year of medical school, and the highest level of depression during the clinical years, from the fourth to the sixth. At admission, the 'Committed' have higher level of depression than the 'Clever'; on the first year, significantly lower than the 'Bright'; on the fourth and fifth years, significantly higher than the 'Clever' and the 'Bright'; and on the sixth year, significantly higher than the 'Clever'. The 'Clever' have the lowest level of depression during the whole of medical studies. At admission, they have significantly lower level than the 'Committed'; on the first and second years, significantly lower level than the 'Bright'; on the fourth, fifth and sixth years, significantly lower level than the 'Committed'. The 'Bright' have the highest level of depression during the basic training years, from admission procedure to the third year, and a moderate level of depression from the fourth to the sixth year. At admission, they have significantly higher level than the 'Clever'; on the first year, significantly higher level than the "Committed' and the 'Clever'; on the second year, significantly higher than the 'Clever'; on the fourth and fifth years, significantly lower level than the 'Committed'.

We found significant differences in state anxiety during medical school between the groups representing different styles of success (Table 2). The groups have different state anxiety levels throughout medical school, except for the fourth year. The 'Committed' have the highest level of state anxiety at admission and during the first year of medical school and a moderate level from the second to the sixth year. They have e616 significantly higher level of state anxiety than the 'Committed' at admission and on the first and fifth year. The 'Clever' have the lowest level of state anxiety during medical studies. At admission and on the first year, they have significantly lower level than the 'Committed'; on the third year, they have significantly lower level than the 'Bright'; on the fifth year, significantly lower level than the 'Committed' and the 'Bright'; and on the sixth year, significantly lower level than the 'Bright'. The 'Bright' have a moderate level of state anxiety at admission and during the first year and the highest level from the second to the sixth year of medical school. They have significantly higher level than the 'Clever' on the second, fifth and sixth years.

We also found significant differences in trait anxiety during medical studies between the groups representing different styles of success (Table 2). The respective styles have different trait anxiety levels from the second to the sixth year. The 'Committed - satisfied with career' have a moderate level of trait anxiety from the second to the sixth year (significantly higher than the 'Clever' on the second, fifth and sixth years). The 'Clever - satisfied with life' have the lowest level of trait anxiety from the second to the sixth year (significantly lower than the 'Committed' on the second, fifth and sixth years; and significantly lower than the 'Bright' from the second to the sixth year). The 'Bright - competent' have the highest level of trait anxiety from the second to the sixth year (significantly higher than the 'Committed' from the second to the sixth year.

The high school final exam result, which is the highest predictor of the future styles of success in medical career is the result of biology exam (Table 3). The higher the result, the 
better prediction of belonging to the first cluster of success the 'Committed - satisfied with career'.

The medical school 1-6th point grade average, which is the highest predictor of the future styles of success, are the result during the second and the fourth years. The higher the GPA, the better the prediction of belonging to the third cluster of success the 'Bright - competent'.

The state anxiety level during medical school, which is the highest predictor of the future styles of success in medical career are the result during the whole medical education, except for the fourth year. The higher the state anxiety at admission, the better the prediction of belonging to the 'Committed'. The lowest state anxiety during the second, fifth and sixth years, the better the prediction of belonging to the 'Clever'.

The trait anxiety level during medical school, which is the highest predictor of the future styles of success in medical career, are the result during the whole medical education, except for the first and fourth years. The lower the trait anxiety at admission, the better the prediction of belonging to the 'Committed'. The higher the trait anxiety during second, fifth and sixth years, the better the prediction of belonging to the 'Clever'. The lower the trait anxiety during the third year, the better the prediction of belonging to the 'Bright.

\section{Discussion}

Three styles of success in the medical career can be differentiated as a result of our research, and predicted subsequently on the basis of earlier anxiety level and academic achievement. Surprisingly, the third factor measured - depression, does not work as a predictor in this case.

The data obtained show remarkable perspective on some aspects of medical doctors' life and professional performance. It is especially interesting that those physicians with the best professional competence have the lowest income. However, physicians with the lowest professional competence gain the highest income. What is more interesting, physicians with the highest QOL (general well-being and life satisfaction) have the lowest professional stress and vulnerability to burnout.

In order to understand the sources of the differences between the groups representing these styles of success, it may be worthwhile analysing the differences between them at admission and during their medical studies.

The first group presented in this article are those we called the 'Committed - satisfied with career'. Membership in this group can probably be predicted on the level of anxiety and depression. They do not differ from the other group in the context of GPA during medical education. They maintain the highest level of anxiety during the preclinical years of medical school. However, it may be assumed that they adapt to their new situation as students quite smoothly, and their level of anxiety in the clinical years of studies is therefore moderate, compared with the other students. Nevertheless, it should be noted that the 'Committed' graduate from medical studies with the highest tendency to depression.

The next style of success in the medical career - the 'Bright - competent' - includes students who receive the highest grades during the second year of their studies. However, the representatives of this group are characterised by the specific contradiction to the 'Committed'. They start with the highest level of depression during preclinical years, which is followed by the highest level of anxiety during clinical years.

The 'Clever - satisfied with life' are individuals who, compared to the other styles, achieve the lowest grades during the second year of their studies. However, the students belonging to this group have at least the same but mostly the lowest level of depression and anxiety in the whole medical education.

What is happening to these groups four years after graduation from medical studies? The most satisfied with medicine as a career are the 'Committed', whereas the 'Clever' and the 'Bright' are less satisfied and they do not differ from each other. This group is also characterised by the same low level of professional competence, as the 'Clever' have. What is more, they display a high psychological burden related to their job and a tendency to burnout, exactly the same as the 'Bright'. It may be their self-perception of low competence that makes the work so stressful to them. This may mean that, comparing to the other two styles of success, they are the most dedicated to their work, and this is the reason their job is such a psychological burden to them. It should also be noted that this style is characterised by a low general well-being and life satisfaction, similar to the 'Bright', but compensated by high income, like in the 'Clever' style. This group should be given special attention during medical school, especially in terms of their tendency to burnout in the future. Therefore, it would be advisable to plan a psychological intervention program for this group during their medical studies. What seems significant is the ability to transfer commitment to non-professional life goals and to maintain distance to the job as the major source of life satisfaction.

The 'Bright' are the most competent physicians, but only moderately satisfied with their career choice as the 'Clevers' are. Work is a psychological burden for them. The general well-being and life satisfaction of the 'Bright' are as low as in the 'Committed' style. What could be more frustrating, they earn the lowest income comparing to the other groups. The 'Bright' group includes individuals who are very talented, but at the same time have the greatest difficulties in managing their lives. A psychological intervention program oriented to this group of students should attempt to transform their external sources of success (e.g. grades) to internal values.

The highest QOL among the three styles of success is obtained by the 'Clever'. They are the happiest and the most satisfied with their life. They earn the highest income together with the 'Committed'. Nevertheless, they are the least overwhelmed by work-related stress. As physicians, the 'Clever' are also characterised by a low level of professional competence, comparable to the 'Committed'. Interestingly, this group is also the least satisfied with the career they have chosen, together with the 'Bright'. At the same time, they seem to be doing the best job of managing their lives. This may be a result of skill deficiency, resulting in an inability to commit to the career. Transferring commitment to other life aims may produce a feeling of routine in performing professional duties in the future. Psychological intervention in the case of this group of students would be aimed at making them more sensitive to the 
emotional context of the doctor-patient relationship. The objective is to make the ability to increase the level of patients compliance a source of life satisfaction and a more essential value.

Each of the styles of success we differentiated not only exhibits adaptive features as far as the medical career is concerned, but also other features that impair the adaptation process. Early identification of the style to which a given medical student belongs would make it easier to optimise the process of adaptation to the medical career.

Taking under consideration this goal, it is worth including the level of anxiety and academic achievements (during the second and fourth years of study) as empirically proven tools to identify specific tendency in career development. Although depression occurred as a non-significant predictor, it seems to deny the usefulness of the tool (the depression scale from MMPI) to measure this variable as questionable. Perhaps medical students do not represent clinical level of depression so the data obtained are not representative for non-clinical group.

Future studies on styles of success in medical training and their predictors should be conducted on a larger research population. Cultural differences between physicians and differences in medical specialisations should also be examined. One limitation of this study is that the results are related to only young medical doctors. This study does not pertain to dropouts from the medical career, which is one of the success factors mentioned in the literature. Those who have given up their medical career are not available for the Polish Chamber of Physicians and Dentists, which was our source of addresses for the medical doctors' who had been participants in the first part of the study. Of the 320 in the cohort, we found only 255 addresses, because of change of address, change of surname after marriage and possible dropouts from the medical career. Of these, only 54 returned our questionnaires. This constitutes serious limitation, which is the small number of participants in the last stage of the research. The question how we could motivate graduated doctors to take part in similar studies is one of the most important challenges for future research. Thus, a distinct study could be designed to clarify the motivation in those who responded to the questionnaire. On the other hand, one advantage of this attempt is that all of the parameters we analysed refer to the same study group, from the beginning of medical school till the fourth year after graduation.

\section{Notes on contributors}

MACIEJ WALKIEWICZ, PhD, is a Psychologist and University Teacher. His primary research interest is in assessing the competence and performance of medical students and practicing doctors.

MALGORZATA TARTAS, PhD, is a Clinical Psychologist, Psychoanalytical Psychotherapist and University Teacher. Her main research interests are in the area of mental disorders in the context of social adaptation.

MIKOLAJ MAJKOWICZ, PhD, is a Clinical Psychologist and a Professor in the Department of Psychology at the Medical University of Gdańsk. His main interests are in the area of psychometric methods especially in quality of life research.

WALDEMAR BUDZINSKI, PhD, is a Clinical Psychologist and University Teacher. His primary research interest is clinical child psychology.

e618

\section{Acknowledgements}

We are very grateful to our respondents for taking part in our research. We would also like to thank Prof. Mariusz Klencki, $\mathrm{MD}, \mathrm{PhD}$, of the Medical Examination Centre, Poland, for permission to analyse the examination results of postgraduates; Zdzislawa Cieplińska, of the Department of Psychology at the Medical University of Gdańsk, for organisational help; Krzysztof Wójcikiewicz, MD, from the Polish Chamber of Physicians and Dentists, Gdańsk, for organisational help; Karol Karasiewicz, PhD, from the Institute of Psychology at the University of Gdańsk, for statistical advice; and Prof. Bruce D. MacQueen, $\mathrm{PhD}$, from the Institute of English at the University of Gdańsk, for language support.

Declaration of interest: The authors report no declarations of interest.

This longitudinal research program was supported by grants ST-50\#1998-2006 and W-139\#2009-2010, funded by the Medical University of Gdańsk, Poland and the Polish Ministry of Science and Higher Education.

\section{References}

Bore M, Munro D, Powis D. 2009. A comprehensive model for the selection of medical students. Med Teach 31(12):1066-1072.

Brennan N, Corrigan N, Allard J, Archer J, Barnes R, Bleakley A, Collett T, de Bere SM. 2010. The transition from medical student to junior doctor: Today's experiences of Tomorrow's Doctors. Med Educ 44(5):449-458.

Cave J, Washer P, Sampson P, Griffin M, Noble L. 2007. Explicitly linking teaching and assessment of communication skills. Med Teach 29:317-322.

Compton MT, Carrera J, Frank E. 2008. Stress and depressive symptoms/ dysphoria among US medical students: Results from a large, nationally representative survey. J Nerv Ment Dis 196(12):891-897.

Czapinski J, Panek T, editors. 2000. Diagnoza Spoleczna 2000. Warunki i jakosc zycia Polakow oraz ich doswiadczenia z reformami systemowymi po 10 latach transformacji. Warsaw: College of Education [in Polish] (Conditions and Subjective Quality of Life in Poland and experience with systemic reforms after 10 years of transformation).

Czapinski J, Panek T, editors. 2003. Diagnoza Spoleczna 2003. Warunki i jakosc zycia Polakow. Warsaw: University of Finance and Management in Warsaw [in Polish]. (Social Diagnosis 2003: Objective and Subjective Quality of Life in Poland).

Czapinski J, Panek T, editors. 2005. Diagnoza Spoleczna 2005. Warunki i jakosc zycia Polakow. Warsaw: University of Finance and Management in Warsaw [in Polish]. (Social Diagnosis 2005: Objective and Subjective Quality of Life in Poland).

Czapinski J, Panek T, editors. 2009. Diagnoza Spoleczna 2009. Warunki i jakosc zycia Polakow. Warsaw: University of Finance and Management in Warsaw [in Polish]. (Social Diagnosis 2009: Objective and Subjective Quality of Life in Poland).

Czapinski J, Panek T, editors. 2011. Diagnoza Spoleczna 2011. Warunki i jakosc zycia Polakow. Warsaw: University of Finance and Management in Warsaw [in Polish]. (Social Diagnosis 2009: Objective and Subjective Quality of Life in Poland).

Dahlin M, Joneborg N, Runeson B. 2005. Stress and depression among medical students: A cross-sectional study. Med Educ 39(6):594-604.

Dyrbye LN, Thomas MR, Massie FS, Power DV, Eacker A, Harper W, Durning S, Moutier C, Szydlo DW, Novotny PJ, et al. 2008. Burnout and suicidal ideation among US medical students. Ann Intern Med 149(5):334-341.

Dyrbye LN, Thomas MR, Shanafelt TD. 2006. Systematic review of depression, anxiety, and other indicators of psychological distress among U.S. and Canadian medical students. Acad Med 81(4):354-373. 
Ferguson E, James D, Madeley L. 2002. Factors associated with success in medical school: Systematic review of the literature. BMJ 324:952-957.

Ferguson E, James D, O'Hehir F, Sanders A, McManus IC. 2003. Pilot study of the roles of personality, references, and personal statements in relation to performance over the five years of a medical degree. BMJ 326(7386):429-432

Fernando N, Prescott G, Cleland G, Greaves K, McKenzie H. 2009. A comparison of the United Kingdom Clinical Aptitude Test (UK-CAT) with a traditional admission selection process. Med Teach 31:1018-1023.

Gattiker UE, Larwood L. 1986. Subjective career success: A study of managers and support personnel. J Bus Psychol 1(2):78-94.

Goho J, Blackman A. 2006. The effectiveness of academic admission interviews: An exploratory meta-analysis. Med Teach 28(4):335-340.

Guthrie E, Black D, Bagalkote H, Shaw C, Campbell M, Creed F. 1998 Psychological stress and burnout in medical students: A 5-year prospective longitudinal study. J R Soc Med 91:237-243.

Hathaway SR, McKinley JC. 1943. Minnesota multiphasic personality inventory. Minneapolis: University of Minnesota Press.

Hathaway SR, McKinley JC. 1951. Minnesota multiphasic personality inventory, manual. New York: Psychological Corporation.

Hughes P. 2002. Can we improve on how we select medical students? J R Soc Med 95:18-22.

Inam SN, Saqib A, Alam E. 2003. Prevalence of anxiety and depression among medical students of private university. J Pak Med Assoc 53(2):44-47.

Kiessling C, Schubert B, Scheffner D, Burger W. 2004. First year medical students' perceptions of stress and support: A comparison between reformed and traditional track curricula. Med Educ 38(5):504-509.

Maslach C, Jackson SE. 1986. Maslach burnout inventory. Palo Alto, CA Consulting Psychologists Press.

Matkowski M. 1992. MMPI badanie - Opracowanie - Interpretacja. Poznań: Pracownia Terapii i Rozwoju Osobowości [in Polish].

McCranie EW, Brandsma JM. 1988. Personality antecedents of burnout among middle-aged physicians. Behav Med 14(1):30-36.

McManus IC, Keeling A, Paice E. 2004. Stress, burnout and doctors attitudes to work are determined by personality and learning style: A twelve year longitudinal study of UK medical graduates. BMC Med 2:29.

McManus IC, Powis DA, Wakeford R, Ferguson E, James D, Richards P. 2005. Intellectual aptitude tests and A levels for selecting UK school leaver entrants for medical school. BMJ 331:555-559.

McManus IC, Richards B, Winder BC, Sproston KA. 1998. Clinical experience, performance in final examinations, and learning style in medical students: Prospective study. BMJ 316(7128):345-350.

McManus IC, Smithers E, Partridge P, Keeling A, Fleming PR. 2003. A levels and intelligence as predictors of medical careers in UK doctors: 20 year prospective study. BMJ 327(7407):139-142.

Miller PM, Surtees PG. 1991. Psychological symptoms and their course in first-year medical students as assessed by the Interval General Health Questionnaire (I-GHQ). Br J Psychiatry 159:199-207.

Newbury-Birch D, Kamali F. 2001. Psychological stress, anxiety, depression, job satisfaction, and personality characteristics in preregistration house officers. Postgrad Med J 77(904):109-111.
Niemi PM, Vainiomaki PT. 2006. Medical students' distress quality, continuity and gender differences during a 6-year medical programme. Med Teach 28(2):136-141.

O'Neill LD, Korsholm L, Wallstedt B, Eika B, Hartvigsen J. 2009. Generalisability of a composite student selection programme. Med Educ 43(1):58-65.

Pamphlett R, Farnill D. 1995. Effect of anxiety on performance in multiple choice examination. Med Educ 29(4):297-302.

Paro H, Morales N, Silva C, Rezende C, Pinto R, Morales R, Mendonca T, Prado M. 2010. Health-related quality of life of medical students. Med Educ 44:227-235.

Pasikowski T. 2000. Polska adaptacja kwestionariusza Maslach Burnout Inventory (Polish adaptation of the Maslach Burnout Inventory). In: Sek $\mathrm{H}$, editors. Wypalenie zawodowe. Przyczyny, mechanizmy, zapobieganie. Warsaw: Wydawnictwo Naukowe PWN [in Polish] (Burnout. The reasons, mechanisms, prevention). 135-148.

Peskun C, Detsky A, Shandling M. 2007. Effectiveness of medical school admissions criteria in predicting residency ranking four years later. Med Educ 41(1):57-64.

Pickard M, Bates L, Dorian M, Greig H, Saint D. 2000. Alcohol and drug use in second-year medical students at the University of Leeds. Med Educ 34(2):148-150.

Powis D. 2009. Personality testing in the context of selecting health professionals. Med Teach 31:1045-1046.

Radcliffe C, Lester H. 2003. Perceived stress during undergraduate medical training: A qualitative study. Med Educ 37(1):32-38.

Rippey RM, Thal S, Bongard SJ. 1981. A study of the University of Connecticut's criteria for admissions into medical school. Med Educ 15(5):298-305.

Roh MS, Jeon HJ, Kim H, Cho HJ, Han SK, Hahm BJ. 2009. Factors influencing treatment for depression among medical students: A nationwide sample in South Korea. Med Educ 43(2):133-139.

Spielberger CD. 1996. Theory and research on anxiety. In: Spielberger CD, editor. Anxiety and behavior. New York: Academic Press. pp 3-20.

Spielberger CD, Gorsuch RL, Lushene RE. 1970. Manual for the state trait anxiety inventory. Palo Alto, CA: Consulting Psychologist's Press.

Stewart SM, Betson C, Lam TH, Marshall IB, Lee PW, Wong CM. 1997. Predicting stress in first year medical students: A longitudinal study. Med Educ 31(3):163-168.

Stewart SM, Lam TH, Betson C, Wong CM, Wong AM. 1999. A prospective analysis of stress and academic performance in the first two years of medical school. Med Educ 33(4):243-250.

Tartas M, Walkiewicz M, Majkowicz M, Budzinski W. 2011. Psychological factors determining success in a medical career: A 10-year longitudinal study. Med Teach 33(3):e163-e172.

White CB, Dey EL, Fantone JC. 2009. Analysis of factors that predict clinical performance in medical school. Adv Health Sci Educ Theory Pract 14(4):455-464. Epub 2007 Nov 21.

Wrześniewski K, Sosnowski T. 1996. Inwentarz stanu i cechy lęku (ISCL); polska adaptacja STAI. Warszawa: Polskie Towarzystwo Psychologiczne - Pracownia Testów Psychologicznych [in Polish]. 